Arq. Bras. Med. Vet. Zootec., v.62, n.6, p.1348-1351, 2010

\title{
Mast cells and angiogenesis in canine mammary tumor
}

[Mastócitos e angiogênese nos tumores mamários caninos]

\author{
G.E. Lavalle, A.C. Bertagnolli, W.L.F. Tavares, M.A.N.D. Ferreira, G.D. Cassali* \\ Laboratório de Patologia Comparada - Departamento de Patologia Geral \\ Instituto de Ciências Biológicas - UFMG \\ 31270-901 - Belo Horizonte, MG
}

\begin{abstract}
The correlation between microvessel density and mast cells density in canine mammary tumors was studied. Sixty-five samples of canine mammary tumors, being 24 benign and 41 malignant, were analyzed. The routine Toluidine Blue staining method was used to assess the mast cells. To evaluate angiogenesis, the immunohistochemical expression of CD31 was assessed. There was no significant difference in either mast cells $(\mathrm{P}=0.44)$ or microvessel density $(\mathrm{P}=0.77)$ between malignant and benign tumors. A positive correlation was observed between microvessel density and mast cells ( $\mathrm{r}=0.39$; $\mathrm{P}=0.011$ ) in malignant tumors. These results suggest that mast cells may play a role in canine mammary malignant tumors development, promoting angiogenesis, similar to some tumors described in the human species.
\end{abstract}

Keywords: bitch, mammary gland, mast cells, microvessel density, neoplasms

\section{RESUMO}

Estimou-se a correlação entre a densidade de microvasos e a densidade de mastócitos em tumores mamários caninos. Sessenta e cinco amostras de tumores mamários caninos - 24 benignos e 41 malignos - foram analisadas, pela técnica rotineira de coloração com Azul de Toluidina para avaliação da densidade de mastócitos. Para a avaliação da angiogênese, foi utilizada a técnica de imunoistoquímica para expressão de CD31. Não foram observadas diferenças significativas de mastócitos $(P=0.44)$ ou densidade microvascular $(P=0.77)$ entre tumores malignos e benignos. A correlação entre densidade microvascular e densidade de mastócitos foi positiva $(r=0,39 ; P=0,011)$ em tumores malignos. Estes resultados sugerem que os mastócitos podem exercer um importante papel no desenvolvimento de tumores mamários malignos caninos mediante promoção da angiogênese, similarmente a alguns tumores descritos na espécie humana.

Palavras-chave: cadela, glândula mamária, mastócitos, densidade microvascular, neoplasias

\section{INTRODUCTION}

Mammary tumors are among the most common neoplasms in women and female dogs (Dutra et al., 2004). Spontaneous mammary tumors in bitches have been proposed as comparative animal models for the study of mammary neoplasms. They can also be used to evaluate

Recebido em 14 de janeiro de 2010

Aceito em 25 de novembro de 2010

*Autor para correspondência (corresponding author)

E-mail: cassalig@icb.ufmg.br

Apoio: CNPq/FAPEMIG new therapeutic strategies, prognostic, and predictive factors (Paoloni and Khanna, 2008).

The growth of newly formed vessels, or angiogenesis, represents an important step in tumor growth and progression in several human and animal tumors (Restucci et al., 2002; Ribatti et al., 2004). High levels of angiogenic factors associated with histological evidence of increased tumor neovascularization, by measurement of microvessel densities, are considered to have important prognostic value in 
human medicine for several solid tumors (Imada et al., 2000; Elpek et al., 2001; Ribatti et al., 2004, Paoloni and Khanna, 2008).

Inflammatory cells such as macrophages, neutrophils, lymphocytes, and mast cells contribute to tumor angiogenesis by releasing potent angiogenic factors stored in their cytoplasm (Ribatti et al., 2004). Several epidemiological, clinical, and experimental studies have demonstrated an association between chronic inflammation and cancer, in which inflammatory mediators contribute to the progression of the illness (Murdoch et al., 2008). According to Ranieri et al. (2003), there is a mutual stimulus among tumor cells, inflammatory cells, and endothelial cells by paracrine mechanisms that result in more intense angiogenesis, tumor development, and dissemination.

Mast cells are normal components of connective tissue, widespread among the organs and tissues of various species. They occur occasionally in bone marrow and rarely in peripheral blood, where their presence is considered abnormal. Mast cells and mast cells densities are highly correlated with normal and pathological extension of angiogenesis, such as chronic inflammatory disease and neoplasms. Mast cells involvement in tumor angiogenesis has been demonstrated in several solid human tumors (Imada et al., 2000; Elpek et al., 2001; Weidner et al., 2001; Kashiwase et al., 2004). The contribution of mast cells to angiogenesis in human tumors is clear but not well established (Murdoch et al., 2008), in veterinary medicine, however, there is no study in the literature with this information. The aim of this study was to examine the correlation between microvessel density and mast cells density canine mammary tumors.

\section{MATERIAL AND METHODS}

Forty-one samples of malignant mammary tumors and 24 samples of benign mammary tumors were retrieved from the files of the Laboratory of Comparative Pathology, Departamento de Patologia Geral, Instituto de Ciências Biológicas at the Universidade Federal de Minas Gerais, Brazil. The selection was based on histopathological diagnosis according to World Health Organization criteria (Leek, 2001).
After reviewing the cases, the malignant tumor group was compound of 11 tubular carcinomas, eight solid carcinomas, and 22 carcinomas in mixed tumors were selected. The benign tumor group was compound of 24 cases, being 10 adenomas, two duct papillomas, and 12 benign mixed tumors.

All tissue samples were routinely fixed in $10 \%$ neutral formalin and embedded in paraffin. Sections of $3 \mu \mathrm{m}$ were cut from one representative block for each case and collected on glass slides. The slides were deparaffined, rehydrated in graded alcohols, and subjected to heat-induced antigen retrieval (water bath at $98^{\circ} \mathrm{C}$ ) with antigen retrieval solution (DAKO, $\mathrm{pH}$ 6.0, CA, Carpinteria). Endogenous peroxidase activity was blocked with $3 \%$ hydrogen peroxidase in methanol.

Each primary antibody was diluted in phosphate buffered saline (PBS) and incubated for 60min at room temperature. The primary antibodies used for immunohistochemical evaluation included an anti-human CD31 mouse monoclonal (JC70A, 1:50 dilution, DAKO, SA, Denmark). The reaction was amplified using the streptavidinbiotin-peroxidase (Lab Vision, Fremont, CA) method and diaminobenzidine (DAB) was used as a chromogen. Slides were counterstained with Mayer's hematoxylin, washed in running water for $5 \mathrm{~min}$, dehydrated, and mounted in a synthetic medium.

Canine mammary carcinomas, known to express CD31, were used as positive controls. Histologically recognizable blood vessels within tissue sections served as internal controls for CD31 immunostaining. Negative controls were obtained by omitting the primary antibodies.

Any isolated stained cell or group of cells, clearly separated from adjacent groups, with or without lumen, was considered as a distinct vessel, as described in previous studies. Areas of fibrosis, necrosis and inflammation, and vessels with muscular layers were not counted (Weidner et al., 1991). The microvessels were counted in the three most vascularized areas, known as hot spots, at 400x magnification, from which the median was obtained.

To determine mast cells density, specimens were stained with Toluidine Blue and 15 fields per 
slide were examined (at 400x magnification), from which the median was obtained.

T-student test was performed to determine whether there was a significant difference in median mast cells or microvessel density between benign and malignant tumors.

\section{RESULTS AND DISCUSSION}

There was no significant difference in either mast cells $(\mathrm{P}=0.44)$ or microvessel density $(\mathrm{P}=0.77)$ counting, comparing malignant versus benign tumors (Table 1). Pearson's correlation test was applied to assess the correlation between microvessel density and mast cells density in benign and malignant tumors separately.

Table 1. Mast cells and microvessel between benign and malignant canine mammary tumors

\begin{tabular}{lcc} 
& Benign Tumors & Malignant tumors \\
\hline Mast cells & & \\
Mean \pm SEM & $7.59 \pm 4.89 \mathrm{a}$ & $6.51 \pm 5.54 \mathrm{a}$ \\
Microvessel density & & $39.45 \pm 24.22 \mathrm{a}$ \\
\hline
\end{tabular}

Means followed by equal letters are statistically similar $(\mathrm{P}<0.05)$ by t-test.

A positive correlation was observed between the arithmetic means of CD31 and mast cells $(\mathrm{r}=0.39 ; \mathrm{P}=0.011)$ in malignant tumors only. In benign tumors, no significant correlation $(\mathrm{P}=0,77)$ was found.

The hystological characteristics of the tumors samples may have contributed to this result, since half of the assessed cases were compound of benign mixed tumors, which is the most common benign tumor in the female dog. Benign mixed tumors are histologically characterized by a mixture of epithelial components (ductal and/or acinous cells and myoepithelial cells) within an apparently mesenchymal stroma, capable of producing different degrees of myxoid, chondroid, and bone tissues. Since canine benign mixed tumors may develop carcinomatous foci resulting in carcinomas (Misdorp et al., 1994), an increased in angiogenesis and mast cells may also mean a precocious event in the malignant progression of these tumors (Figure 1).

No previous study evaluating the correlation between mast cells and angiogenesis in canine mammary tumors was found in the literature.

The contribution of mast cells to the development of angiogenesis in human tumors is clear but not well established (Murdoch et al., 2008). One evidence of the mast cells involvement in neoplasm development is the presence of a greater number of mast cells in malignant human breast tumors than in benign tumors (Kashiwase et al., 2004) In addition, mast cells density has been found to correlate with an increased risk of metastasis in several malignancies (Ribatti et al., 2004).

Tumoral angiogenesis is the ability of neoplastic cells inducing the formation of new vessels and it is also required for tumor growth above $2 \mathrm{~mm}$ (Weidner et al., 1991). Many authors correlate microvessel density and prognosis in human breast cancer (Leek, 2001). Recent studies have been shown similar results in veterinary medicine (Restucci et al., 2002).

In human breast cancer, Imada et al. (2000) and Ribatti et al. (2004) found a significant correlation between mast cells density and angiogenesis. Mast cells have been found in higher concentrations around tumors, next to neoformed vessels (Ribatti et al., 2004). Experimental studies support the view that neovascularisation is influenced by mast cellderived angiogenic mediators (vascular endothelial growth factor - VEGF) or growth factors (Elpek et al., 2001; Norrby, 2002).

It has been recently demonstrated that hypoxia can be one important factor for the stimulation of mast cells to degranulate and to secrete angiogenic factors in vitro (Murdoch et al., 2008). 


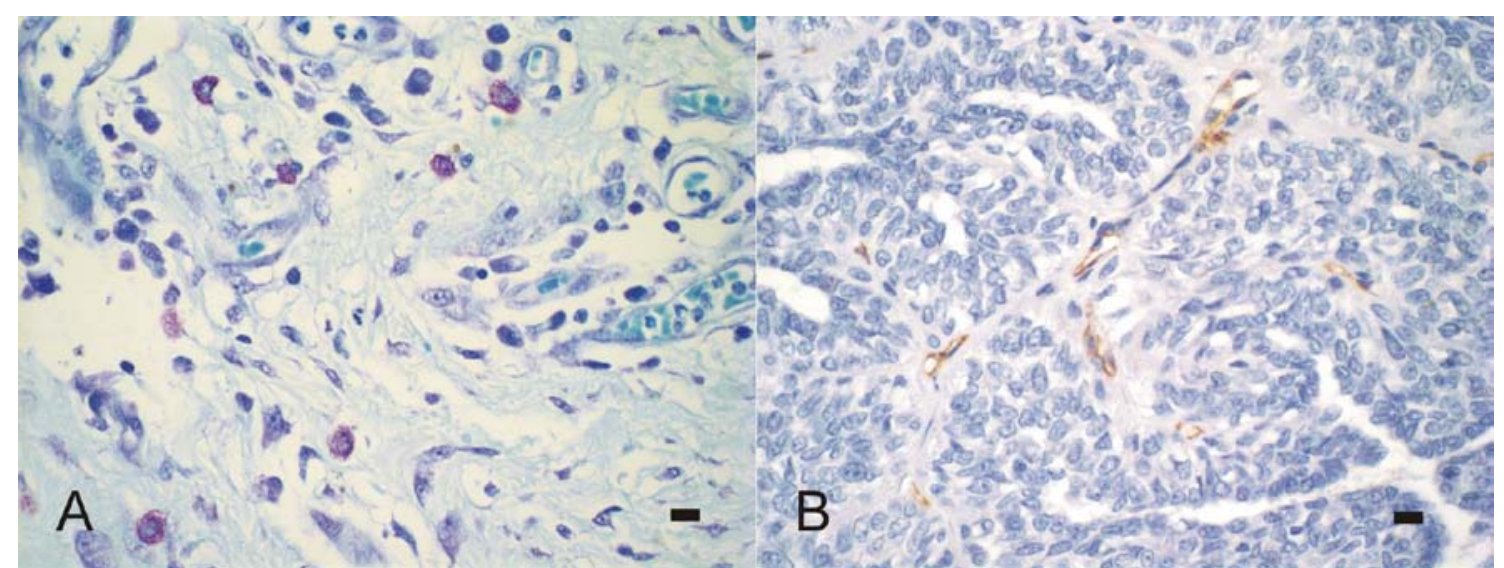

Figure 1. Canine mammary tumor. A) Toluidine Blue staining for mast cells evidence. B) Immunohistochemistry with CD31 endothelium-vascular protein marking. Bar $=10$ microns.

\section{CONCLUSIONS}

These results suggest that mast cells may play a role in canine mammary malignant tumors development, promoting angiogenesis, similar to some tumors described in the human species. However, the precise functional relevance of mast cells in tumors is unclear, suggesting that further research is necessary for better understanding.

\section{REFERENCES}

DUTRA, A.P.; GRANJA, N.V.M.; SCHMITT, F.C. et al. C-Erbb-2 Expression and nuclear pleomorphism in canine mammary tumors: comparative aspects with human breast tumor. Braz. J. Med. Biol. Res., v.37, p.1673-1681, 2004.

ELPEK, G.O.; GELEN, T.; AKSOY, N.H. et al. The prognostic relevance of angiogenesis and mast cell in squamous cell carcinoma of the oesophagus. J. Clin. Pathol., v.54, p.940-944, 2001.

IMADA, A.; SHIJUBO, N.; KOJIMA, H. et al. Mast cells correlate with angiogenesis and poor outcome in stage I lung adenocarcinoma. Eur. Resp. J., v.15, p.1087-1093, 2000.

KASHIWASE, Y.; MORIOKA, J.; INAMURA, H. et al. Quantitative analysis of mast cell in benign and malignant breast lesions. Immunohistochemical study on formalin - Fixed, paraffin- embedded tissues. Int. Arch. Allergy Immunol., v.134, p.199205, 2004.

LEEK, R.D. The prognostic role of angiogenesis in breast cancer. Anticancer Res., v.21, p.4325- 4331, 2001.
MISDORP, W.; ELSE, R.W.; HELLMÉN, E. et al. Histological classification of the mammary tumors of the dog and the cat. 2.ed. Washington, DC: Armed Forces Institute of Pathology, 1999.

MURDOCH, C.; MUTHAMA, M.; COEFFELT, S.B. et al. The role of mieloid cells in the promotion of tumor angiogenesis. Nat. Rev. Cancer, v.8, p.618-631, 2008.

NORRBY, K. Mast cell and angiogenesis - review article. Apmis, v.110, p.355-371, 2002.

PAOLONI, M.; KHANNA, C. Translation of new cancer treatments from pet dogs to humans. Nat. Rev. Cancer, v.8, p.147-156, 2008.

RANIERI, G.; PASSANTINO, L.; PSTRUNO, R. et al. The dog mast cell tumour as a model to study the relationship between angiogenesis mast cell density and tumour malignancy. Oncol. Rep., v.10, p.1189-1193, 2003.

RESTUCCI, B.; PAPPARELLA, S.; MAIOLINO, $P$. et al. Expression of vascular endothelial growth factor in canine mammary tumors. Vet. Pathol., v.39, p.488-493, 2002.

RIBATTI, D.; CRIVELLATO, E.; ROCCAROT, A.M. et al. Mast cell contribution to angiogenesis related to tumour progression. Clin. Exp. Allergy, v.34, p.1660-1664, 2004.

WEIDNER, N.; SEMPLE, J.P.; WELCH, W.R. et al. Tumor angiogenesis and metastasis correlation in invasive breast carcinoma. N. Engl. J. Med., v.334, p.1-8, 1991. 